\title{
Freshwater lichens in springs of the eastern Italian Alps: floristics, ecology and potential for bioindication
}

\author{
J. Nascimbene ${ }^{1 *}$, H. Thüs ${ }^{2}$, L. Marini ${ }^{3}$, P.L. Nimis ${ }^{1}$ \\ ${ }^{1}$ Department of Biology, University of Trieste, via Giorgieri 10 - 34100 Trieste, Italy. \\ ${ }^{2}$ Department of Plant Ecology and Systematics, Technical University of Kaiserslautern, Erwin Schrödinger-Str., 67653 Kaiserslautern, Germany. \\ ${ }^{3}$ Department of Environmental Agronomy and Crop Production, University of Padova, viale dell’Università 16 - 35020 Legnaro, Padova, Italy.
}

\begin{abstract}
Freshwater habitats of the Italian Alps are largely unexplored and further floristic-ecological surveys are needed to clarify the role of freshwater lichens in these environments. This applies especially to springs, since they seem to be suitable for a relatively high number of aquatic species due to their ecological stability. The present work is focused on springs in an alpine region, and is centered on: (a) floristics of freshwater lichens of the Italian Alps, (b) ecological and morphological information on potential indicator species for calcareous and siliceous springs. The study was carried out in the eastern Italian Alps on 36 perennial springs. Single springs proved to host a surprisingly low number of species, while at regional level the entire pool of investigated springs host a relevant lichen flora representing $45 \%$ of the freshwater lichens of the Italian Alps. One species is new to Italy and 3 are new to Trentino-Alto Adige. Biodiversity conservation measures should therefore be planned at regional level, including a whole network of sites in different altitudinal belts and with different substrates. Verrucaria elaeomelaena and V. funckii are the most frequent species on calcareous and siliceous springs respectively. They are suggested as potential indicator species, since they proved to be indicative of the main physical, ecological and hydrochemical features of their habitat. A detailed morphological description of these two species is also provided in order to enhance their identification by environmentalists.
\end{abstract}

Keywords: aquatic lichens, biomonitoring, conservation, CRENODAT, indicator species.

\section{Introduction}

Springs are a complex habitat, highly sensitive to disturbance (primarily water abstraction) and therefore in urgent need of conservation. They have a limited seasonal fluctuation in physiochemistry (Cantonati et al. 2006), and host several groups of specialized organisms, including freshwater lichens. In their extensive review on the hydrobiology of Alpine springs, Cantonati et al. (2006) summarised the main chemical-physical and biotic features of this habitat, focusing on its importance for biodiversity conservation.

Lichens mostly colonise terrestrial habitats, but a few species are restricted to submerged or partially inundated rocks, such as in springs, rivers, and lakes (Thüs 2002). Freshwater lichens belong to a few genera, the most representative being Verrucaria. In spite of their limited number, they are often difficult to identify by non-specialists. The taxonomical position of several species still awaits further research, and often the morphological characters used in the identification keys are not clear, or

* Corresponding author: E-mail: junasc@libero.it deserve a critical review (e.g. Aptroot \& Seaward 2003). Taxonomical problems are a constraint for advances in ecological studies and for the use of freshwater lichens as biomonitors. Nascimbene \& Nimis (2006) provided a review on freshwater lichens of the Italian Alps, underlining that further floristic and ecological surveys are needed to clarify the role of this poorly known guilt in the freshwater habitats of the Alps (e.g. Nascimbene 2006, Thor \& Nascimbene 2007). This applies especially to springs, which are suspected to host a relatively high number of aquatic species due to their ecological stability. However, most of the information on freshwater lichens in the Alps is in the form of floristic surveys (e.g. Keller 2000), mainly focused on streams, while springs are only marginally considered (Cantonati et al. 2006).

In freshwater habitats, species distribution is known to be affected by several ecological factors related to the length of submergence, shading, substrate (lithology, stability), water chemistry, speed and transportation (Aptroot \& Seaward 2003, Gilbert 1996, Gilbert \& Giavarini 1997, 2000, Mühlenhoff \& Büdel 1995, Thüs 2002). However, information on their effects is still scanty (e.g. Davis et al. 2000, 2003, Gilbert \& Giavarini 1997, Pentecost 
1977, Ried 1960a, b), especially in the alpine environment (e.g. Keller \& Scheidegger 1994). Nascimbene \& Nimis (2006) suggested to concentrate further research in those sites where chemical-physical and ecological data related to water and habitat quality are available, in order to relate the occurrence of freshwater species to physical and biological parameters. A recent multidisciplinary project in the north-estern Italian Alps (CRENODAT, see Cantonati et al. 2005) was focused on springs, providing a complex database in which the values of several ecological parameters are available for c. 100 springs. The present work, which relates biological and CRENODAT data, is focused on springs in an alpine region, and is centered on: (a) floristics of freshwater lichens of the Italian Alps, (b) ecological and morphological information on potential indicator species for calcareous and siliceous springs.

\section{Materials and methods}

\section{Study sites and lichen survey}

The study was carried out in the province of Trento (NE Italy) on 36 perennial springs not impacted by artificial structures for water abstraction and homogenously distributed in the study area. Their main features are summarized in Table 1. The altitudinal distribution ranges from the submediterranean ( 3 sites) to the montane (24 sites) and subalpine/alpine (9 sites) belts. Seventeen springs are on siliceous rocks and 19 on calcareous rocks. According to the ecomorphological classification of springs by Steinmann (1915) and Thienemann (1922), all of the selected sites are rheocrene, while according to the geomorphological classification by Howein \& Schroeder (2006), based on the granulometric features of the substrate, they belong to different types, mainly cobble (21 sites) and bolder (9 sites) springs. Light availability and water speed were estimated on a five classes ordinal scale. Water transportation is expressed on a three level ordinal scale (Table 1). Most of the springs are in partially shaded conditions (shading $25-75 \%$ ), have a low water speed $\left(<50 \mathrm{~cm} \mathrm{~s}^{-1}\right)$, and water transportation $\left(<1-51 \mathrm{~s}^{-1}\right)$. The percentage of inorganic and organic sediments, water temperature, percentage of $\mathrm{O}_{2}$, water $\mathrm{pH}$ measured at $20^{\circ} \mathrm{C}$, conductivity, alkalinity, N-NO 3 , N-tot, $\mathrm{P}_{-} \mathrm{PO}_{4}, \mathrm{P}-$ tot, $\mathrm{SiO}_{2}, \mathrm{SO}_{4}, \mathrm{Cl}, \mathrm{Ca}, \mathrm{Mg}, \mathrm{Na}, \mathrm{K}, \mathrm{D}$.O.C. were directly measured according to standard protocols (APAT, 2004; APHA, 2000; Cantonati et al., in press.) and the values of two series of data were averaged.

In each spring, lichens were collected both in perennially and periodically inundated micro-sites in the first 5 meters from the headwater. Species nomenclature follows Nimis \& Martellos (2003), except for Verrucaria funckii (Thüs 2002).

\section{Indicator species}

An Indicator Species Analysis (Dufrêne \& Legendre 1997) was used to describe differences in species composition and frequency between calcareous and siliceous springs, and to determine how strongly each species was associated with its substrate. For each species, the Indicator Value (IV) ranges from 0 (no indication) to 100 (maximum indication). Statistical significance of IV was tested by a Montecarlo test, based on 1000 randomizations. This analysis was performed by PC-ORD (McCune \& Mefford 1997). Significant indicator species were subjected to a morphological and ecological description.

\section{Results \\ Floristics}

Thirty-four species were found (Table 2). Verrucaria funckii is new to Italy. According to Orange (2004) and Thüs (2006), it is not a synonym of V. pachyderma (Nimis 2003), which is known from a single locality in Trentino-Alto Adige (Nimis 1993). Thelidium inundatum, a poorly known species that deserves further study, Staurothele solvens, and Hymenelia cyanocarpa are new to Trentino-Alto Adige. Following Nimis $(1993,2003)$, the species belong to three main ecological guilds on the basis of their water requirements (Table 2):

1) Species of perennially inundated habitats and therefore most sensitive to water features. Six species belong to this guild, five of which are Verrucaria. The most frequent (V. aquatilis, V. rheitrophila, V. elaeomelaena, $V$. funckii) are associated with highly specialised algae: either Dilabifilum sp. a filamentous green alga or Heterococcus caespitosus (Tschermak-Woess 1988, Thüs 2002) a representative of the Xanthophyta. At higher altitude, the diversity of associated green algal phcyobionts increases: Verrucaria latebrosa is associated with Stichococcus sp. (Thüs unpublished) and Dermatocarpon rivulorum with Diplosphaera chodatii (Reháková 1968). All of them reproduce by ascospores. Verrucaria elaeomelaena and V. funckii are the most frequent species on calcareous and siliceous springs, respectively (14 and 12 sites). The former was found in all altitudinal belts, while the latter is lacking at low altitudes (submediterranean belt). Verrucaria aquatilis was found both in calcareous and in siliceous springs;

2) Semi-aquatic species of periodically inundated habitats. Thirteen lichens belong to this guild, mostly species of Ionaspis, Staurothele, and Verrucaria. Two species have a trentepohlioid photobiont, and two reproduce by lichenised propagules (Hymenelia 
Table 1. Main features of the 36 investigated springs. aID: identification code of the spring according to the CRENODAT project; ${ }^{\mathrm{b}}$ Frwl: number of freshwater lichens in each site; ${ }^{\mathrm{C}}$ Rock: represent the rock type of the spring. $\mathrm{C}=$ carbonatic; $\mathrm{S}=$ siliceous; ${ }^{\mathrm{d}}$ Alt.: altitude $(\mathrm{m})$; ${ }^{ } \mathrm{Esp} .:$ esposition $\left({ }^{\circ}\right) ;{ }^{\mathrm{f}}$ Spring typ.: spring typology according to the geomorphological classification of springs by Howein \& Schroeder (2006); ${ }^{\text {SSha- }}$ ding: shading conditions of the habitat expressed on a five level ordinal scale (1) completely exposed; (2) shading reaching $25 \%$; (3) shading reaching 50\%; (4) shading reaching $75 \%$; (5) shading $>75 \%$; ${ }^{\text {S Speed: }}$ water speed expressed on a five level ordinal scale (1) $0-<10 \mathrm{~cm} \mathrm{~s}^{-1}$; (2) $<30 \mathrm{~cm} \mathrm{~s}^{-1}$; (3) $<50 \mathrm{~cm} \mathrm{~s}^{-1}$; (4) 50 $-100 \mathrm{~cm} \mathrm{~s}^{-1} ;(5)>100 \mathrm{~cm} \mathrm{~s}^{-1}$; ${ }^{i} \mathrm{~W}$ trans.: water transportation expressed on a three level ordinal scale. (1): $<1 \mathrm{l} / \mathrm{s} ;(2): 1-5 \mathrm{l} / \mathrm{s} ;$; $(3):>51 / \mathrm{s}$.

\begin{tabular}{|c|c|c|c|c|c|c|c|c|c|}
\hline $\mathrm{ID}^{\mathrm{a}}$ & Locality & Frwl $^{\text {b }}$ & Rock $^{c}$ & Alt. ${ }^{d}$ & Esp. ${ }^{e}$ & Spring typ. ${ }^{f}$ & Shading $^{\mathrm{g}}$ & Speed $^{\mathrm{h}}$ & W transp.' \\
\hline CV0992 & Val Tamburli & 1 & $\mathrm{C}$ & 992 & 90 & bolder spring & 4 & 2 & 2 \\
\hline MB1439 & Toghe & 1 & $\mathrm{C}$ & 1440 & 215 & cobble spring & 2 & 2 & 1 \\
\hline BR0470 & Maso Gori & 2 & $\mathrm{C}$ & 470 & 135 & bolder spring & 4 & 5 & 3 \\
\hline LD1400 & Cortelì & 1 & $\mathrm{C}$ & 1400 & 180 & bolder spring & 3 & 4 & 1 \\
\hline $\mathrm{BC} 0564$ & Laurel & 1 & $\mathrm{C}$ & 565 & 315 & cobble spring & 2 & 3 & 2 \\
\hline LD1501 & Tormendos & 1 & $\mathrm{C}$ & 1502 & 135 & cobble spring & 2 & 3 & 1 \\
\hline AD0905 & Vermongo & 1 & $\mathrm{C}$ & 905 & 45 & bolder spring & 3 & 3 & 3 \\
\hline MD1871 & Fedaia & 1 & $\mathrm{C}$ & 1871 & 315 & cobble spring & 2 & 4 & 2 \\
\hline PS1250 & Val Canali & 2 & $\mathrm{C}$ & 1250 & 180 & cobble spring & 4 & 3 & 2 \\
\hline BR1764 & Corna Rossa & 1 & $\mathrm{C}$ & 1765 & 270 & cobble spring & 3 & 3 & 2 \\
\hline BS1526 & Viotte & 1 & $\mathrm{C}$ & 1527 & 0 & cobble spring & 2 & 2 & 1 \\
\hline BR1358 & Nambi & 3 & $\mathrm{C}$ & 1358 & 315 & bolder spring & 3 & 4 & 2 \\
\hline BR1378 & Rislà & 3 & $\mathrm{C}$ & 1379 & 315 & cobble spring & 2 & 3 & 2 \\
\hline BR2239 & Vallazza & 1 & $\mathrm{C}$ & 2240 & 180 & bolder spring & 4 & 3 & 2 \\
\hline АT0971 & Masere & 1 & $\mathrm{C}$ & 972 & 90 & cobble spring & 5 & 2 & 1 \\
\hline BR 1315 & Valagola & 3 & $\mathrm{C}$ & 1315 & 315 & cobble spring & 3 & 2 & 2 \\
\hline BR1436 & Scala di Brenta & 2 & $\mathrm{C}$ & 1436 & 45 & rock spring & 3 & 5 & 1 \\
\hline LD0927 & Del Graì & 1 & $\mathrm{C}$ & 928 & 0 & gravel spring & 3 & 2 & 1 \\
\hline MP0656 & Vallarsa & 1 & $\mathrm{C}$ & 656 & 315 & cobble spring & 5 & 3 & 2 \\
\hline CV1200 & Perengola & 1 & $\mathrm{~S}$ & 1200 & 270 & rock spring & 3 & 4 & 2 \\
\hline CV0962 & Pian Gran & 1 & $\mathrm{~S}$ & 962 & 315 & bolder spring & 5 & 2 & 1 \\
\hline CV1215 & Peterlazet & 1 & $\mathrm{~S}$ & 1215 & 270 & cobble spring & 4 & 3 & 2 \\
\hline CV2051 & Aia dei Sorgati & 3 & $\mathrm{~S}$ & 2051 & 45 & cobble spring & 2 & 3 & 2 \\
\hline CV1280 & Val Calamento & 1 & $\mathrm{~S}$ & 1280 & 0 & cobble spring & 5 & 3 & 2 \\
\hline AN1685 & Malga Gavazzi & 1 & $\mathrm{~S}$ & 1685 & 45 & cobble spring & 2 & 2 & 1 \\
\hline CV1684 & Campigol dei Solai & 1 & S & 1685 & 180 & bolder spring & 4 & 3 & 2 \\
\hline AD2153 & Conca delle Levade & 9 & $\mathrm{~S}$ & 2153 & 135 & cobble spring & 1 & 3 & 2 \\
\hline AD1990 & Palone-Siniciaga & 1 & $\mathrm{~S}$ & 1990 & 315 & cobble spring & 2 & 3 & 2 \\
\hline AD1853 & Malga Val di Fumo & 2 & $\mathrm{~S}$ & 1853 & 215 & gravel spring & 1 & 2 & 2 \\
\hline AD1300 & Borzago & 2 & $\mathrm{~S}$ & 1300 & 180 & cobble spring & 4 & 3 & 3 \\
\hline AD2739 & Adamello & 1 & $\mathrm{~S}$ & 2739 & 215 & bolder spring & 1 & 3 & 3 \\
\hline AD1234 & Ponte Prese & 2 & $\mathrm{~S}$ & 1235 & 180 & cobble spring & 4 & 3 & 1 \\
\hline AD1653 & Val d'Arnò & 1 & $\mathrm{~S}$ & 1654 & 90 & cobble spring & 2 & 2 & 1 \\
\hline BR0804 & Pissidrina sud & 1 & $\mathrm{~S}$ & 804 & 0 & gravel spring & 3 & 2 & 1 \\
\hline LT1239 & Daiano & 1 & $\mathrm{~S}$ & 1240 & 225 & cobble spring & 4 & 2 & 1 \\
\hline OC2278 & Pian Venezia & 5 & $\mathrm{~S}$ & 2278 & 90 & gravel spring & 2 & 2 & 1 \\
\hline
\end{tabular}

ochrolemma, and Koerberiella wimmeriana). Six species form apothecia and three perithecia. Most of them were found in alpine/subalpine springs. Only Verrucaria margacea is present from the submediterranean to the alpine belt.

3) Terrestrial species growing on sheltered and humid rocks. Fifteen lichens belong to this guild, mostly species of Polyblastia, Porpidia, and Verrucaria. Two species have a trentepohlioid photobiont, four produce apothecia and nine perithecia. They are mainly montane, and grow on humid calcareous rocks. These species grow in the peripheral part of the springs and mark a transition to other rocky habitats. 
Table 2. Species list ordered according to 3 ecological groups on the basis of water requirement. Species: nomenclature follows (Nimis \& Martellos, 2003), except for Verrucaria funckii (Thüs, 2002). Ecological groups: $\mathrm{In}=$ species of perennially inundated habitats; $\mathrm{Sa}=$ semi-aquatic species of periodically inundated habitats; Ter $=$ terrestrial species growing on sheltered and humid rocks. Altitudinal belt: Sub = submediterranean; Mont $=$ montane; $\mathrm{Sub} / \mathrm{Alp}=$ subalpine and alpine. Substrate: $\mathrm{Ca}=$ carbonatic rocks; $\mathrm{Si}=$ siliceous rocks. IV: observed Indicator Value ‘**' Marks $\mathrm{p}<0.001$; ' ${ }^{\circ}$ ' Marks new species to Italy; ' $\circ$ ' Marks new species to Trentino-Alto Adige.

\begin{tabular}{|c|c|c|c|c|c|c|c|c|c|c|}
\hline \multirow[t]{2}{*}{ Species } & \multirow[t]{2}{*}{$\mathrm{N}^{\circ}$ of sites } & \multicolumn{3}{|c|}{ Ecological groups } & \multicolumn{3}{|c|}{ Altitudinal belt } & \multicolumn{2}{|c|}{ Substrate } & \multirow[t]{2}{*}{ IV } \\
\hline & & In & $\mathrm{Sa}$ & Ter & Sub & Mont & Sub/Alp & $\mathrm{Ca}$ & $\mathrm{Si}$ & \\
\hline Dermatocarpon rivulorum & 1 & + & & & & & + & & + & 5.9 \\
\hline Verrucaria aquatilis & 3 & + & & & + & + & & + & + & 6.8 \\
\hline Verrucaria elaeomelaena & 14 & + & & & + & + & + & + & & $73.7^{* *}$ \\
\hline Verrucaria funckii ${ }^{\circ \circ}$ & 12 & + & & & & + & + & & + & $64.7^{* *}$ \\
\hline Verrucaria latebrosa & 1 & + & & & & & + & & + & 5.9 \\
\hline Verrucaria rheitrophila & 1 & + & & & & + & & + & & 5.3 \\
\hline Aspicilia aquatica & 2 & & + & & & & + & & + & 11.8 \\
\hline Bacidina inundata & 1 & & + & & & & + & & + & 5.9 \\
\hline Hymenelia cyanocarpa $^{\circ}$ & 1 & & + & & & & + & & + & 5.9 \\
\hline Ionaspis lacustris & 1 & & + & & & & + & & + & 5.9 \\
\hline Ionaspis odora & 1 & & + & & & & + & & + & 5.9 \\
\hline Koerberiella wimmeriana & 2 & & + & & & & + & & + & 11.8 \\
\hline Rhizocarpon lavatum & 3 & & + & & & & + & & + & 17.6 \\
\hline Staurothele fuscocuprea & 1 & & + & & & & + & & + & 5.9 \\
\hline Staurothele solvens ${ }^{\circ}$ & 1 & & + & & & + & & + & & 5.3 \\
\hline Staurothele succedens & 3 & & + & & & + & & + & & 15.8 \\
\hline Thelidium imundatum ${ }^{\circ}$ & 1 & & + & & & + & & + & & 5.3 \\
\hline Verrucaria hydrela & 5 & & + & & & + & & + & + & 19.2 \\
\hline Verrucaria margacea & 6 & & + & & + & + & + & + & + & 9.3 \\
\hline Gyalecta jenensis & 1 & & & + & & + & & + & & 5.3 \\
\hline Hymenelia ochrolemma & 1 & & & + & & & + & & + & 5.9 \\
\hline Petractis clausa & 1 & & & + & & + & & + & & 5.3 \\
\hline Polyblastia albida & 1 & & & + & & + & & + & & 5.3 \\
\hline Polyblastia sepulta & 1 & & & + & & + & & + & & 5.3 \\
\hline Polyblastia cfr. ventosa & 1 & & & + & & + & & + & & 5.3 \\
\hline Porpidia glaucophaea & 1 & & & + & & & + & & + & 5.9 \\
\hline Porpidia macrocarpa & 2 & & & + & & & + & & + & 11.8 \\
\hline Protoblastenia calva & 1 & & & + & & + & & + & & 5.3 \\
\hline Rhizocarpon badioatrum & 1 & & & + & & & + & & + & 5.9 \\
\hline Staurothele rupifraga & 1 & & & + & & + & & + & & 5.3 \\
\hline Thelidium minutulum & 1 & & & + & & + & & + & & 5.3 \\
\hline Thelidium papulare & 1 & & & + & & + & & + & & 5.3 \\
\hline Verrucaria dufourii & 1 & & & + & & + & & + & & 5.3 \\
\hline Verrucaria cfr. muralis & 1 & & & + & & + & & + & & 5.3 \\
\hline
\end{tabular}

Table 3. Results of the morphological analysis on Verrucaria elaeomelaena (six specimens from different sites) and V. funckii (10 specimens from different sites). Mean values and standard error are expressed in $\mu . \mathrm{SL}=$ spore length; $\mathrm{SW}=$ spore width; SL/SW $=$ ratio between spore length and spore width; TT = thallus thickness; EW = excipulum width; EH = excipulum height; IT = involucrellum thickness; IW = involucrellum width; $\mathrm{IH}=$ involucrellum height.

\begin{tabular}{lccccccccc}
\hline & & & \multicolumn{7}{c}{ Morphological parameters } \\
& SL & SW & SL/SW & TT & EW & EH & IT & IW & IH \\
\hline Verrucaria elaeomelaena & $24.4 \pm 1.6$ & $12.3 \pm 1$ & $2.0 \pm 0.2$ & $75.0 \pm 39.4$ & $243.3 \pm 44.1$ & $170 \pm 33.5$ & $64.2 \pm 19.6$ & $436.7 \pm 83.8$ & $200 \pm 26.1$ \\
$\mathrm{n}^{\circ}$ of measurements & 60 & 60 & 60 & 6 & 6 & 6 & 6 & 6 & 6 \\
Verrucaria funckii & $21.4 \pm 1.7$ & $9.0 \pm 1$ & $2.4 \pm 0.3$ & $140.2 \pm 39.5$ & $217.2 \pm 45.6$ & $180.3 \pm 40.1$ & $46.6 \pm 13.5$ & $391.8 \pm 82.7$ & $234.8 \pm 52.2$ \\
$\mathrm{n}^{\circ}$ of measurements & 95 & 95 & 95 & 10 & 10 & 10 & 10 & 10 & 10 \\
\hline
\end{tabular}



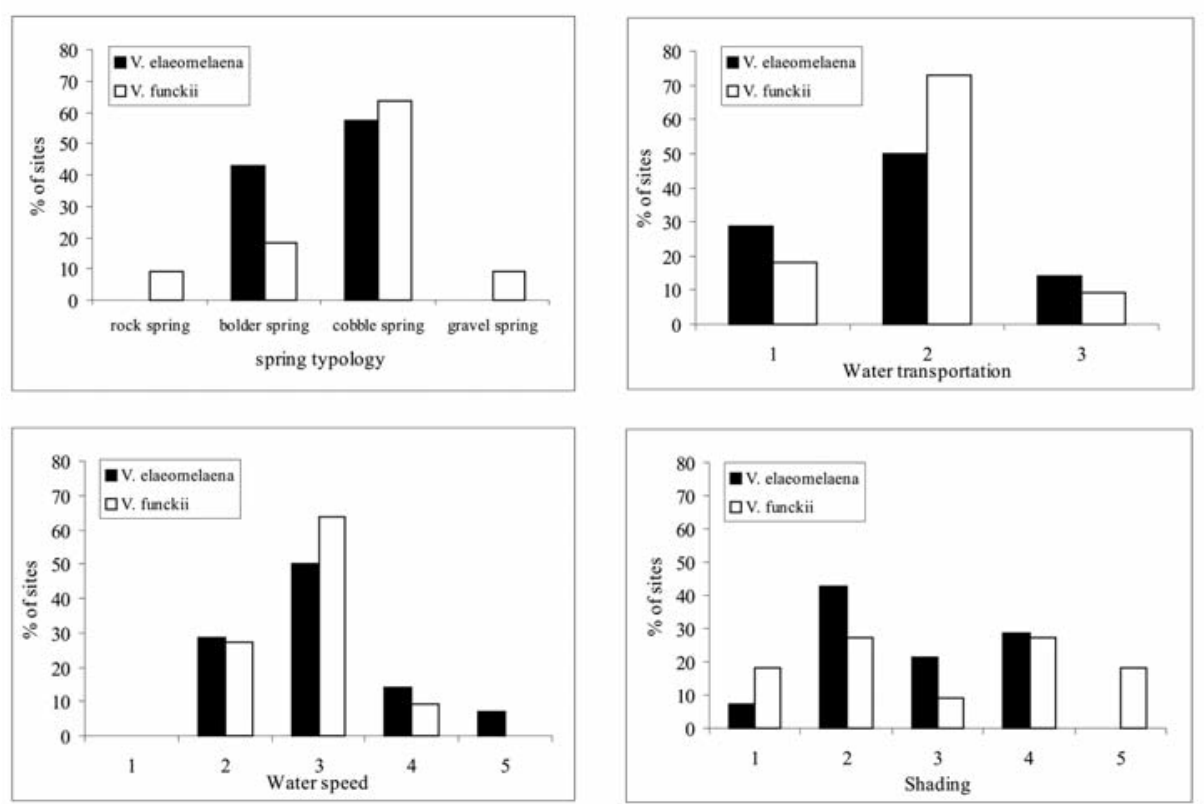

Fig. 1. Occurrence of Verrucaria elaeomelaena and $V$. funckii in different springs types and in different conditions of water transportation, water speed, and shading. See notes to Table 1 for additional remarks on the values used in the $\mathrm{X}$ axis.

Both the species of guild 1 and 2, which represent $62 \%$ and $45 \%$ of the freshwater lichens occurring in Trentino Alto Adige and in the Italian Alps, respectively, properly belong to the spring habitat. Their total richness decreases from the alpine/subalpine (13) to the montane (9) and submediterranean belt (3), and from siliceous (14) to calcareous (8) springs (Table 2). Considering species richness at spring level (Table 1), this is surprisingly low: $83 \%$ of the sites host 1-2 species, with no significant difference between calcareous and siliceous springs.

\section{Indicator species}

In the last column of Table 2 the results of the Indicator Species Analysis are reported. Due to the low frequency of the species in the springs, the Indicator Values are generally low. However, two significant indicator species were found: Verrucaria elaeomelaena for calcareous springs (IV=73.7, $P=0.001)$, and Verrucaria funckii for siliceous springs (IV=64.7, $P=0.001)$.

\section{Morphological and ecological description of the two indicator species}

The indicator species Verrucaria elaeomelaena and Verrucaria funckii are very similar and were often confused (see discussion). Therefore, we present a detailed description of their main morphological features (Table 3). The two species significantly differ (t-test) in the dimen- sions of the spores (SL, SW; $P<0.01)$ and in the ratio between spores length and width $(P<0.01)$, those of V. elaeomelaena being typically "egg-shaped" and larger than those of $V$. funckii. The thallus is green, brown-olivegreenish to greyish, well developed and normally without fissures in both species. However, its thickness is significantly higher $(P<0.01)$ in $V$. funckii. The other morphological features do not significantly differ between the two species. Spore dimensions and the ratio length/width have a relatively restricted range of variation, indicating a considerable stability of this character in the study area. The other characters have a high variability in both species.

The occurrence of the two species seems to be related to some physical, ecological and hydrochemical features of the sites (Fig.1; Tables 4 and 5). They generally prefer bolder and cobble springs with intermediate conditions of water transportation (1-5 $\left.1 \mathrm{~s}^{-1}\right)$ and speed $\left(30-50 \mathrm{~cm} \mathrm{~s}^{-1}\right)$. Both species are tolerant to shading, growing also in densely forested sites where shading reaches or exceeds $75 \%$. Some hydrochemical parameters (conductivity, and $\mathrm{Mg}$ and $\mathrm{Na}$ contents) proved to significantly differ between sites in which Verrucaria elaeomelaena occurs and sites in which the species was not found. Analogously, springs with Verrucaria funckii significantly differ in $\mathrm{pH}$, conductivity, alkalinity, and $\mathrm{Cl}, \mathrm{Mg}$, and $\mathrm{SiO}_{2}$ contents from those in which the species was not found. 
Table 4. Comparison of chemical-physical variables in calcareous springs classified on the basis of the occurence of Verrucaria elaeomelaena. * Marks parameters that significantly differ $(\mathrm{p}<0.05)$ between springs where the species is present and absent.

\begin{tabular}{|c|c|c|c|c|c|c|c|c|}
\hline & \multicolumn{8}{|c|}{ Verrucaria elaeomelaena } \\
\hline & \multicolumn{4}{|c|}{ Present } & \multicolumn{4}{|c|}{ Absent } \\
\hline & mean & ds & $\min$ & $\max$ & mean & ds & $\min$ & $\max$ \\
\hline$\%$ inororganic sediments & 49.29 & 22.69 & 10 & 90 & 52.00 & 21.68 & 30 & 80 \\
\hline$\%$ organic sediments & 50.71 & 22.69 & 10 & 90 & 38.00 & 28.64 & 0 & 70 \\
\hline $\mathrm{T}^{\circ}$ & 6.48 & 1.70 & 3 & 8.57 & 7.21 & 1.70 & 5.35 & 9.5 \\
\hline $\mathrm{O} 2 \%$ & 85.97 & 8.63 & 71.9 & 100 & 85.83 & 6.48 & 80 & 94 \\
\hline $\mathrm{pH}$ & 7.92 & 0.19 & 7.47 & 8.14 & 7.97 & 0.19 & 7.73 & 8.26 \\
\hline Conductivity $(\mu \mathrm{S} / \mathrm{cm})$ & $314.71^{*}$ & 299.65 & 144 & 1338 & $273.6^{*}$ & 129.11 & 79 & 413 \\
\hline Alkalinity (mg/l) & 129.65 & 33.60 & 82.3 & 210 & 161.00 & 58.05 & 98 & 231 \\
\hline $\mathrm{N}-\mathrm{NO}_{3}(\mu \mathrm{g} / \mathrm{l})$ & 773.79 & 471.36 & 229.3 & 1823.4 & 831.40 & 229.83 & 658.5 & 1230 \\
\hline Ntot $(\mu \mathrm{g} / 1)$ & 833.57 & 502.48 & 259 & 1940 & 903.00 & 200.10 & 710 & 1230 \\
\hline $\mathrm{P}^{-\mathrm{PO}_{4}}(\mu \mathrm{g} / \mathrm{l})$ & 3.34 & 3.56 & 0.00 & 13.00 & 2.32 & 1.29 & 1.10 & 4.2 \\
\hline Ptot $(\mu \mathrm{g} / 1)$ & 8.02 & 9.91 & 1.40 & 36.60 & 6.10 & 2.46 & 2.70 & 8.8 \\
\hline $\mathrm{SiO}_{2}(\mathrm{mg} / \mathrm{l})$ & 2.71 & 1.57 & 0.55 & 5.44 & 1.79 & 0.31 & 1.34 & 2.06 \\
\hline $\mathrm{SO}_{4}(\mathrm{mg} / \mathrm{l})$ & 59.65 & 206.80 & 1.20 & 778.00 & 11.13 & 13.78 & 3.04 & 35.49 \\
\hline $\mathrm{Cl}(\mathrm{mg} / \mathrm{l})$ & 1.10 & 1.32 & 0.19 & 4.60 & 2.23 & 3.63 & 0.32 & 8.714 \\
\hline $\mathrm{Ca}(\mathrm{mg} / \mathrm{l})$ & 61.79 & 67.31 & 18.21 & 288.19 & 43.09 & 10.45 & 31.77 & 59.76 \\
\hline $\mathrm{Mg}(\mathrm{mg} / \mathrm{l})$ & $9.48^{*}$ & 13.21 & 1.28 & 54.00 & $16.69^{*}$ & 7.79 & 8.75 & 26.08 \\
\hline $\mathrm{Na}(\mathrm{mg} / \mathrm{l})$ & $0.95^{*}$ & 1.21 & 0.12 & 4.43 & $1.26^{*}$ & 1.76 & 0.26 & 4.40 \\
\hline $\mathrm{K}(\mathrm{mg} / \mathrm{l})$ & 0.45 & 0.49 & 0.00 & 1.71 & 0.67 & 0.51 & 0.27 & 1.291 \\
\hline D.O.C. $(\mathrm{mg} / \mathrm{l})$ & 1.10 & 0.74 & 0.40 & 3.10 & 1.60 & 1.31 & 0.56 & 3.9 \\
\hline
\end{tabular}

\section{Discussion}

Springs of the Alps proved to be a suitable habitat for several aquatic lichens, and some species have a promising potential for bioindication, since they are indicative of the main physical and hydrochemical features of this habitat.

Most of the aquatic species are known to occur in the Italian Alps only from old records (Nimis 1993, 2003), confirming the urgent need of further studies on this poorly known guild whose richness and conservation status were so far overlooked. Analogously to other freshwater habitats, the occurrence and richness of aquatic species in springs seems to be related to altitude and substrate. The altitudinal distribution of aquatic species belonging to the spring habitat follows the pattern described by Nascimbene \& Nimis (2006) for the freshwater lichen flora of the Italian Alps, with a higher diversity in the subalpine/alpine belt. It is however remarkable that Verrucaria margacea was found also at low altitudes $(600 \mathrm{~m})$, since it was always regarded as a montane to alpine taxon (Zschacke 1934, Thüs 2002, Orange 2000). Cantonati et al. (2006) considered springs as azonal or extrazonal habitats, due to the constant and low temperatures that enhance the presence of stable vegetation and of glacial relicts. Therefore, the unusual occurrence of V. margacea at low altitudes could be considered dependent on these special thermal conditions. On the contrary, the species does not occur in submediterranean creeks, or rivers where temperatures vary to a larger degree, depending on
Table 5. Comparison of chemical-physical variables in siliceous springs classified on the basis of the occurence of Verrucaria funckii. * Marks parameters that significantly differ $(\mathrm{p}<0.05)$ between springs where the species is present and absent $* *$ Marks $\mathrm{p}<0.01$.

\begin{tabular}{|c|c|c|c|c|c|c|c|c|}
\hline & \multicolumn{8}{|c|}{ Verrucaria funckii } \\
\hline & \multicolumn{4}{|c|}{ Present } & \multicolumn{4}{|c|}{ Absent } \\
\hline & mean & ds & $\min$ & $\max$ & mean & ds & $\min$ & $\max$ \\
\hline$\%$ inororganic sediments & 54.54 & 28.00 & 10 & 100 & 61.50 & 32.89 & 30 & 100 \\
\hline$\%$ organic sediments & 45.45 & 28.00 & 0 & 90 & 42.67 & 40.01 & 1 & 100 \\
\hline $\mathrm{T}^{\circ}$ & 5.98 & 2.32 & 2.9 & 11.7 & 7.35 & 1.06 & 5.75 & 8.1 \\
\hline $\mathrm{O}_{2} \%$ & 85.43 & 9.16 & 65 & 97.7 & 85.04 & 17.18 & 59.2 & 105 \\
\hline $\mathrm{pH}$ & $6.72^{*}$ & 0.52 & 5.9 & 7.68 & $7.4^{*}$ & 0.81 & 6.05 & 8.04 \\
\hline Conductivity $(\mu \mathrm{S} / \mathrm{cm})$ & $53^{*}$ & 39.72 & 11 & 157 & $204.5^{*}$ & 200.90 & 14 & 568 \\
\hline Alkalinity $(\mathrm{mg} / \mathrm{l})$ & $18.6^{*}$ & 15.15 & 3.5 & 56.7 & $84.33^{*}$ & 61.43 & 5 & 150 \\
\hline $\mathrm{N}-\mathrm{NO}_{3}(\mu \mathrm{g} / \mathrm{l})$ & 390.38 & 303.70 & 107.5 & 1224.4 & 447.77 & 296.85 & 135.20 & 972.80 \\
\hline Ntot $(\mu \mathrm{g} / 1)$ & 476.00 & 306.74 & 215.00 & 1272.00 & 519.00 & 355.52 & 134.00 & 1134 \\
\hline $\mathrm{P}_{-} \mathrm{PO}_{4}(\mu \mathrm{g} / \mathrm{l})$ & 3.80 & 3.00 & 0.90 & 10.80 & 3.57 & 3.37 & 0.00 & 9.80 \\
\hline Ptot $(\mu \mathrm{g} / \mathrm{l})$ & 8.39 & 3.85 & 2.40 & 13.90 & 5.88 & 3.77 & 0.30 & 11.10 \\
\hline $\mathrm{SiO}_{2}(\mathrm{mg} / \mathrm{l})$ & $7.30^{* *}$ & 2.56 & 4.30 & 12.50 & $3.26 * *$ & 1.82 & 2.09 & 6.40 \\
\hline $\mathrm{SO}_{4}(\mathrm{mg} / \mathrm{l})$ & 6.69 & 7.10 & 1.07 & 25.18 & 29.09 & 61.23 & 0.82 & 153.91 \\
\hline $\mathrm{Cl}(\mathrm{mg} /)$ & 0.40 & 0.39 & 0.12 & 1.50 & 0.83 & 0.81 & 0.14 & 2.08 \\
\hline $\mathrm{Ca}(\mathrm{mg} / \mathrm{l})$ & 8.40 & 8.31 & 1.44 & 30.99 & 31.99 & 31.34 & 2.51 & 87.65 \\
\hline $\mathrm{Mg}(\mathrm{mg} / \mathrm{l})$ & $0.66^{* *}$ & 0.33 & 0.19 & 1.01 & $8.33^{* 0}$ & 7.95 & 0.20 & 21.36 \\
\hline $\mathrm{Na}(\mathrm{mg} / \mathrm{l})$ & 1.56 & 1.00 & 0.35 & 3.58 & 1.68 & 1.88 & 0.27 & 5.15 \\
\hline $\mathrm{K}(\mathrm{mg} / \mathrm{l})$ & 0.53 & 0.20 & 0.25 & 0.84 & 0.55 & 0.38 & 0.00 & 1.04 \\
\hline D.O.C. $(\mathrm{mg} / \mathrm{l})$ & 1.15 & 1.02 & 0.43 & 4.00 & 0.88 & 0.34 & 0.37 & 1.30 \\
\hline
\end{tabular}

the surrounding air temperature. The lichen flora of siliceous springs is richer in species than that on calcareous springs, indicating a higher suitability of siliceous rocks for aquatic lichens in the Alps (Nascimbene \& Nimis 2006). Most of the species are restricted to different rock types, while only a few (Verrucaria aquatilis, $V$. hydrela s.l., and V. margacea) are able to establish both on calcareous and on siliceous substrates. The number of species occurring on both substrata becomes even smaller, if the separation of V. hydrela and V. calcaria is applied. We followed Nimis (2003) treating Verrucaria calcaria Zsch. as a synonym to $V$. hydrela, although apart from its different ecology (calcareous instead of siliceous substrata) a new character was observed that might help to distinguish the two taxa. In $V$. hydrela the angle between the involucrellum and the lower part of the exciple is transparent and the cellwalls in this area are colourless, while in V. calcaria this area is filled by cells with distinctly brown cell walls. These differences are also visible in the type specimens of V. hydrela and V. calcaria, but if this single character is sufficient for the separation on a species level remains open to debate. A revision of the $V$. hydrela-group including molecular data is urgently needed and currently in progress (Thüs unpublished).

Verrucaria funckii and V. elaeomelaena are the most frequent species of siliceous and calcareous springs, respectively, confirming the ecological remarks by Zschacke (1934), and Orange (2000) who reported these species as typical of springs in Central Europe and in the British Isles. 
Despite the fact that they are similar in the colour of the thallus and often confused with each other (Orange 2000, but see also Swinscow 1968, Hawksworth 1989, Keller 2000), they proved to be different in the thickness of the thallus and in the morphology of spores. The morphological characters of both species are in the range of those available in literature (Orange 2000, Purvis et al. 1993, Thüs 2002, Wirth 1995), which however indicate that they could be highly variable, especially in spore size. For example Orange (2000) indicates different spores sizes than Purvis et al. (1993) in the British Isles. In the study area spore size proved to be relatively stable and the values measured in $V$. funckii correspond to the detailed description by Thüs (2002) based on Central European material.

The potential for bioindication of these two species is corroborated by the ecological description, which revealed that they are indicative of some important features of their habitat. The high suitability of bolder and cobble springs is probably related to substrate stability which is indispensable for freshwater lichens (Thüs 2002). Water transportation and speed could influence both the submersion of the thalli and their establishment, being related to the inundation period, to the formation of splash water and to the probability of erosion effects. An intermediate condition proved to be an important habitat quality for the two Verrucaria, which seems to be hindered by both low (desiccation) and high (erosion) water transportation and speed values. The effects of these factors are partially related to shading, which enhances the tolerance of the species to desiccation by improving air humidity. Verrucaria funckii is very desiccation-sensitive if air humidity is low, while it can survive above the water level if air humidity is constantly high (Ried 1960a, 1960b). Shady conditions may therefore compensate for shorter submersion periods. According to the results of Pentecost (1977) and Gilbert \& Giavarini (1997), some chemical factors related to spring lithology such as $\mathrm{pH}$, conductivity, alkalinity, silica and $\mathrm{Mg}$ values (Cantonati et al. 2006) seem to influence the occurrence of the two Verrucaria species, suggesting their relation to water chemistry. Verrucaria elaeomelaena and V. funckii are therefore suggested as potential indicator species for rapid monitoring purposes on the basis of four main reasons: (a) they are widespread in a wide range of environments and altitudinal belts and can be considered as typical spring lichens, (b) they are strictly bound to different lithology, (c) they are clearly visible, having a well developed thallus, and can be identified by spore size and shape, and (d) their occurrence is indicative for certain physical and hydrochemical factors related to springs ecology.
Our study gives new insights into an overlooked lichen habitat revealing that the potential of springs for aquatic lichen richness seems to be highly dependent on the scale. Single springs proved to host a surprisingly low number of species, while at regional level the entire pool of investigated springs host a relevant aquatic lichen flora. This pattern has important implications for conservation, suggesting that the protection of single sites is not an effective measure, and that a biodiversity conservation plan for spring habitats should be necessarily developed at regional level, including a whole network of sites in different altitudinal belts and with different substrates.

\section{Acknowledgements}

This work is part of the CRENODAT Project, a multidisciplinary study of the springs of Trentino, coordinated by Museo Tridentino di Scienze Naturali (Trento) and founded by the Provincia Autonoma di Trento. We thank M. Cantonati (Trento) for stimulating discussions and important suggestions.

\section{References}

APAT. 2004 - Metodi analitici per le acque. Manuali e Linee Guida, 29/2003, $1150 \mathrm{p}$.

APHA. 2000. - Standard Methods for the Examination of Water and Wastewater. $20^{\text {th }}$ ed., APHA, AWWA \& WEF, Washington D.C.

Aptroot A. \& Seaward M.R.D. 2003. - Freshwater lichens. Fungal Diversity Research Series, 10, 101-110.

Cantonati M., Angeli N., Bertuzzi E., Lazzara M., Spitale D., Guella G. \& Oss Cazzador P. 2005. - The CRENODAT Project (Biodiversity assessment and integrity evaluation of springs of Trentino Italian Alps - and long-term ecological research). $4^{\text {th }}$ Symposium for European Freshwater Sciences. Jagiellonian University, Krakow, Poland 22-26 August 2005, Abstract book.

Cantonati M., Gerecke R. \& Bertuzzi E. 2006. - Springs of the Alps sensitive ecosystems to environmental change: from biodiversity assessments to long-term studies. Hydrobiologia , 562, 59-96.

Cantonati M., De Cet F., Corradini F. \& Bertuzzi E. (in press.). The significance of chemical and physical factors influencing the ecology of springs and a case study in the South-eastern Alps (Dolomiti Bellunesi National Park). In The spring habitat: Biota and sampling methods. Cantonati M., Bertuzzi E. \& Spitale D. (eds.) Monografie del Museo Tridentino di Scienze Naturali 4.

Davis W. C., Gries C. \& Nash T.H. III. 2000. - The ecophysiological response of the aquatic lichen Hydrothyria venosa to nitrates in terms of weight and photosynthesis over long periods of time. In New Aspects in Cryptogamic Research. Contributions in Honour of Ludger Kappen. Schroeter B., Schlensog M. \& Green T.G.A (eds.) Bibl. Lich. 75, 201-208.

Davis W.C., Gries C. \& Nash, T.H. III.2003. - The influence of temperature on the weigth and net photosynthesis of the aquatic lichen Peltigera hydrothyria over long periods of time. In Lichenological contrbutions in honour of G.B. Feige. Jensen M. (ed.) Bibl. Lich. 86, 233-242.

Dufrêne M. \& Legendre P. 1997. - Species assemblages and indicator species: the need for a flexible asymmetrical approach. Ecol. Monogr., 67, 345-366.

Gilbert O.L. 1996. - The lichen vegetation of chalk and limestone steams in Britain. Lichenologist, 28, 145-159.

Gilbert. O.L. \& Giavarini V.J. 1997 - The lichen vegetation of acid watwrcourses in England. Lichenologist, 29, 347-367. 
Gilbert. O.L. \& Giavarini V.J. 2000. - The lichen vegetation of lake margins in Britain. Lichenologist, 32, 365-386.

Hawksworth D.L. 1989. - Notes on aquatic species of Verrucaria in the British Isles. Lichenologist, 21, 23-28.

Howein H. \& Schroeder H. 2006. - Geomorphologische Untersuchungen. In Gerecke R. \& Franz H. (Eds.) Quellen im Nationalpark Berchtesgaden. Faunistisch-ökologische Untersuchungen und Perspektiven für die langfristige Umweltbeobachtung. Nationalpark Berchtesgaden, Forschungsbericht, 51, 71-86.

Keller C. 2000. - Die Wasserflechten der Teigitsch zwischen der Langmannsperre und dem Kraftwerk Arnstein (Steiermark, Österreich). Herzogia , 14, 49-58.

Keller C. \& Scheidegger C. 1994. - Zur Verbreitung von Wasserflechten in Abhängigkeit zur jährlichen Überflutungsdauer im Flüelatal (Schweiz, Kanton Graubünden). Herzogia, 10, 99-114.

McCune B. \& Mefford M.J. 1999. - Multivariate analysis of ecological data. Version 4.25. MjM Software, Gleneden Beach, OR, US.

Mühlenhoff D. \& Büdel B. 1995. - Vergleich der Wassermoos- und wasserflechtenvegetation zweier Bachtypen (Waldbäche/ Wiesenbäche) im Spessart. Nova Hedwigia, 61, 525-545.

Nascimbene J. 2006. - Lichenological studies in N-Italy: new records for Lombardy. Cryptogamie Mycologye, 27, 79-82.

Nascimbene J. \& Nimis P.L. 2006. - Freshwater lichens of the Italian Alps: a review. Ann. Limnol. - Int. J. Lim., 42, 27-32.

Nimis 1993 - The lichens of Italy. An annotated catalogue. Museo Regionale di Scienze Naturali,Torino, 897 p.

Nimis P.L. 2003. - Checklist of the Lichens of Italy 3.0. University of Trieste, Dept. of Biology, IN3.0/2 (http://dbiodbs.univ.trieste.it/).

Nimis P.L. \& Martellos S. 2003. - A second checklist of the lichens of Italy with a thesaurus of synonyms. Museo Regionale di Scienze Naturali, Saint-Pierre, Aosta.

Orange A. 2000. - Verrucaria Schrader (freshwater species). In: Lichen Atlas of the British Isles, Fascicle 5, Seaward M.R.D. (ed.). British Lichen Society, London.

Orange A., 2004. - A remarkable new freshwater Verrucaria from Europe. Lichenologist, 36, 349-354.

Pentecost A. 1977. - A comparison of the lichens of two mountain streams in Gwynedd. Lichenologist, 9, 107-111.
Purvis O.W., Coppins B.J., Hawksworth D.L., James P.V. \& Moore D.M. 1993. - The Lichen flora of Great Britain and Ireland. Natural History Museum Publications - London.

Reháková H. 1968. - Lisejníkové rasy z rodu Trebouxia, Diplosphaera a Myrmecia (Flechtender Gattungen Trebouxia, Diplosphaera und Myrmecia). Candidate dissertation, Katedra Bot., University of Karlova, Praha, 176 pp.

Ried A., 1960a. - Stoffwechsel und Verbreitungsgrenzen von Flechten I. Flechtenzonierungen an Bachufern und ihre Beziehungen zur jährlichen Überflutungsdauer und zum Mikroklima. - Flora 148: 613-638.

Ried A., 1960b. - Stoffwechsel und Verbreitungsgrenzen von Flechten II: Wasser- und Assimilationshaushalt, Entquellungs- und Submersionsresistenz von Krustenflechten benachbarter Standorte. Flora, 149, 345-385.

Steinmann P. 1915 - Praktikum der Süßwasserbiologie 1. Teil. Die Organismen des fließenden Wassers.- Sammlung naturwiss. Praktikum, 7, 184 S., 118 Abb.; Berlin (Borntraeger).

Swinscow T.D.V. 1968. - Pyrenocarpous lichens: 13. freshwater species of Verrucaria in the British Isles. Lichenologist, 4: 34-54.

Thienemann A. 1922 - Hydrobiologische Untersuchungen an Quellen (I-IV) - Arch. Hydrobiol., 14, 151-190.

Thor G. \& Nascimbene J. 2007. - A floristic survey in the Southern Alps: additions to the lichen flora of Italy. Cryptogamie, Mycologie, 28, 247-260.

Thüs H. 2002. - Taxonomie, Verbreitung ond Ökologie silicicoler subwasserflechten im auseralpinen Mitteleuropa. Bibliotheca Lichenologica, 83, 1-214.

Thüs H., 2006. - Neufunde und Bemerkungen zur Gefährdung amphibischer Flechten aus dem Saarland und Rheinland-Pfalz. Delattinia, 32, 127-140.

Tschermak-Woess E., 1988. - The algal partner. - In Handbook of Lichenology. Galun M. (Hrsg.) 1, 31 - 92. Boca Raton, Florida.

Wirth V. 1995. - Die Flechten Baden - Württembergs. Ulmer - Stuttgart. 2 voll.

Zschacke H., 1934. - Epigloeaceae, Verrucariaceae und Dermatocarpaceae. In: Rabenhorst's Kryptogamenflora 9/1 (1), 1-695, Leipzig. 